Гостра К. В. аспірант, асистент кафедри російської філології та зарубіжної літератури Криворізький державний педагогічний університет gostra555@gmail.com

\title{
МЕТОДИЧНА РОЗРОБКА ІНТЕГРОВАНОГО УРОКУ «ЗАРУБІЖНА ЛІТЕРАТУРА - РОСІЙСЬКА МОВА - АНГЛІЙСЬКА МОВА»
}

У публікації представлено методичну розробку інтегрованого уроку «Зарубіжна література - російська мова англійська мова». 3 англійської мови автоматизуються дії учнів з лексичним матеріалом з теми «Одяг», з російської мови - удосконалюються орфоографрічні, слухо-вимовні навички учнів з теми «Звуки речи», із зарубіжної літератури узагальнюються знання з теми «Творчість О. С. Пушкіна». На уроці розвиваються вміння учнів монологічного та діалогічного мовлення, фрормуються вміння використовувати крилаті вислови та працювати з художнім текстом.

Ключові слова: інтегрований урок; англійська мова; російська мова; зарубіжна література; крилаті вирази; «Казка про царя Салтана» О. С. Пушкіна.

Гострая Е. В. аспирант, ассистент кафредры русской филологии и зарубежной литературы Криворожский государственный педагогический университет gostra555@gmail.com

\section{МЕТОДИЧЕСКАЯ РАЗРАБОТКА ИНТЕГРИРОВАННОГО УРОКА «ЗАРУБЕЖНАЯ ЛИТЕРАТУРА - РУССКИЙ ЯЗЫК - АНГЛИЙСКИЙ ЯЗЫК»}

В публикации представлена методическая разработка интегрированного урока «Зарубежная литература русский язык - английский язык». По английскому языку автоматизируются действия учеников с лексическим материалом по теме «Одежда», по русскому языку - усовершенствуются орфографические, слухо-произносительные навыки учеников по теме «Звуки речи», по зарубежной литературе обобщаются знания по теме «Творчество А. С. Пушкина». На уроке развиваются умения в монологической и диалогической речи учеников, формируются умения употреблять крылатые выражения в речи и работать с художественным текстом.

Ключевые слова: интегрированный урок; английский язык; русский язык; зарубежная литература; крылатые выражения; "Сказка о царе Салтане» А. С. Пушкина.

Hostra, Kateryna, Postgraduate student, assistant of the Department of Russian Philology and Foreign Literature Kryvyi Rih State Pedagogical University gostra555@gmail.com

INTEGRATIVE LESSON PLAN

\section{«FOREIGN LITERATURE — RUSSIAN — ENGLISH»}

This work presents the integrative lesson in «Foreign literature - the Russian language - the English language». The vocabulary on the topic "Clothes» is revised in English , the theme "Sounds of Speech» is revised in Russian, the theme "The Work of O.S. Pushkin» is summarised in Foreign Literature. The skills of monologic and dialogical speech are improved, the skills of working with cliches, sayings and literary text are developed.

Keywords: integrative lesson; the English language; the Russian language; Foreign literature; clichés and sayings; "The Tale of Tsar Saltan» by O. S. Pushkin.

Клас: 5

ТЕМА УРОКУ: «Три девицы под окном...» ЦІЛІ УРОКУ:

Практичні:

- систематизувати матеріал із теми «Звуки та букви»;

- узагальнити знання учнів твору О. С. Пушкіна «Казка про царя Салтана»;

- автоматизувати дії учнів з англомовними лексичними одиницями з теми «Одяг» на рівні фрази;

- розвивати вміння учнів описувати малюнки до казки та відповідати на запитання вчителя англійською та російською мовами; формувати вміння учнів працювати 3 художнім текстом;

Розвивальна: розвивати творчу уяву, логічне мислення, пам'ять, пізнавальну активність, увагу.

Освітня: вчити учнів використовувати знання та вміння індивідуальної та групової роботи на практиці; розширювати словниковий запас школярів за рахунок крилатих висловів;

Bиховна: виховувати в учнів толерантність, повагу до інших народів і культур, розвивати інтерес до казок народів світу, до іноземних мов; мотивувати учнів до вивчення іноземних мов і необхідність користування ними як засобом спілкування в умовах міжкультурної комунікації; виховувати в учнів жагу до нових знань і створювати умови для використання здобутих знань на практиці.

Методична: використовувати міжпредметні зв'язки 3 метою активізації пізнавальної діяльності учнів та застосовувати отримані знання на практиці.

Тип уроку: комбінований.

Форма уроку: інтегрований: російська мова, зарубіжна література, англійська мова.

Прийоми: «робота в групах», «робота в парах», «мозковий штурм», «реконструкція», «шифрувальник», «редактор», «знайди зайве», «упізнай».

Обладнання: ілюстрації до казки О. С. Пушкіна, 


\section{МЕТОДИКА НАВЧАННЯ ІНОЗЕМНИХ МОВ І КУЛЬТУР У ПОЧАТКОВІЙ ШКОЛІ}

епіграф, роздавальний матеріал - крилаті вислови 3 казки, назви казок О. С. Пушкіна; аудіозапис музичного номеру «Політ джмеля» 3 опери М. А. Римського-Корсакова «Казка про царя Салтана», відеозапис казки, лялька «Джон».

\section{Хід уроку}

\section{I. Організаційний момент}

Учитель: доброе утро, дети! Рада вас всех приветствовать на нашем уроке! Давайте друг другу улыбнёмся и начнём работать!

\section{II. Підготовка до сприймання іншомовного матеріалу:}

Учитель: у нас сегодня необычный урок. Как ваше настроение? (Дети отвечают хором).

Посмотрите, пожалуйста, на доску (там находится портрет А. С. Пушкина), кто это? А на каком языке он писал? Поэтому сегодня на уроке русского языка мы будем учить не только русский язык, но и литературу. А. С. Пушкин всегда хотел знать много языков и владел многими - французским, немецким, греческим, латынью, старославянским, испанским, итальянским, интересовался украинским, польским, сербским, арабским, древнееврейским языками. Ещё мне стало известно, что к нам сегодня приедет гость из Великобритании, его зовут Джон (кукла), он очень хочет познакомиться с вами и сказками великого поэта. А вот и он. Давайте поздороваемся с Джоном! (Дети здороваются с гостем на английском языке.) Вы поможете нашему гостю? Уверена, что вы продемонстрируете знания не только русского языка и литературы, но и английского языка. Я знаю, что вы очень хорошо знаете английский, поэтому с лёгкостью справитесь!

\section{III. Актуалізація знань учнів}

\section{1. Склади таблицю}

Учитель: сегодня мы с вами будем работать с художественным текстом, с крылатыми выражениями, с фразеологизмами. Для разминки давайте заполним таблицу. Перед вами термины на разных языках (украинском, английском, русском) и их определение по-русски, соотнесите их.

\begin{tabular}{|c|c|c|c|}
\hline $\begin{array}{l}\text { фрразео- } \\
\text { логизм }\end{array}$ & idioms & $\begin{array}{l}\text { устойчивое } \\
\text { выражение, неде- } \\
\text { лим, работает как } \\
\text { единое целое }\end{array}$ & фрразеологізм \\
\hline $\begin{array}{l}\text { крылатое } \\
\text { выра- } \\
\text { жение }\end{array}$ & $\begin{array}{l}\text { catch } \\
\text { phrases }\end{array}$ & $\begin{array}{l}\text { фразы из } \\
\text { фольклорных и } \\
\text { литературных } \\
\text { произведений, } \\
\text { могут функциони- } \\
\text { ровать вне текста- } \\
\text { исходника }\end{array}$ & $\begin{array}{l}\text { крилатий ви- } \\
\text { слів }\end{array}$ \\
\hline
\end{tabular}

\section{2. Вправа «Мозковий штурм».}

Учитель: давайте мы повторим материал, выученный на прошлых уроках русского языка, эти знания нам сегодня понадобятся:

Что такое буква?

Что такое звук?

На какие группы делятся звуки русского языка?

В чём отличие устной и письменной речи?

\section{IV. Мотивація навчальної діяльності учнів}

\section{1. Вправа «Реконструкція»}

Учитель: как вы уже поняли, сегодня мы будем работать с фразеологизмами и крылатыми выражениями. Эпиграфом к нашему уроку будет фразеологизм, но вам необходимо его восстановить, слова у меня перемешались, поэтому нужна ваша помощь. Посмотрите на группы слов: здесь представлены три фразеологизма на трёх языках, объединённые общим смыслом, общим значением. Если какое-либо слово вам незнакомо - спросите, и я объясню, особенно обратите внимание на английские слова:

\begin{tabular}{|l|l|l|}
\hline Труд, и, пере- & I, всього, працею, & Is, mother, diligence, \\
трут, всё, тер- & досягнеш, зусил- & success, of. (Dili- \\
пение. (Терпе-- & лям (Зусиллям i \\
ние и труд всё & працею всь is the mother of \\
перетрут.) & сягнеш.) & $\begin{array}{l}\text { success. Дословный } \\
\text { перевод: Усердие- } \\
\text { мать успеха.) }\end{array}$ \\
\hline
\end{tabular}

Учитель: Как вы понимаете эти выражения? Что их объединяет? Согласны ли вы с этим утверждением? Когда их уместно употреблять?

\section{Проверка д/з:}

Учитель: вы должны были перечитать «Сказку о царе Салтане» А. С. Пушкина и повторить звуки и буквы русского языка, справились? А повторили ли вы слова, выученные на уроке английского языка?

Отлично! Молодцы!

Давайте вспомним эти слова. На экране вы увидите изображение, назовите его по-английски. Это очень важно, ведь именно эти слова нам помогут объяснить Джону, что происходит на уроке.

Предметы: бочка - barrel.

Одежда: сарафан - sundress, рубашка - shirt, caпоги - boots, shoes; штаны - trousers, шляпа - hat, пояс - belt.

Зверушки, птицы, насекомые, встречающиеся в тексте: мышонок - little mouse, лягушка - frog, лебедь - swan, комар - mosquito, белка - squirrel, шмель - bumblebee.

Названия людей: сын - son, ребенок - child, царь - king, царица - queen, девица - girl, maiden. 


\section{2. Оголошення теми та мети уроку.}

Учитель: Сегодня мы с вами повторим звуки речи русского языка, слова, выученные на уроках английского языка, а также сказку А. С. Пушкина, которую вы читали на уроках зарубежной литературы. А назвала я наш урок «Три девицы под окном...» Как вы думаете, почему именно так? Я вам помогу, посмотрите видео и тогда ответьте (демонстрируется фрагмент видеозаписи «Сказки о царе Салтане»).

\section{3. Прослуховування музичного номера «Політ} джмеля» - уривка із опери Миколи Андрійовича Римського-Корсакова «Казка про царя Салтана»

Учитель: Сейчас вы послушаете уникальное произведение. Музыканты соревнуются в том, кто быстрее сыграет. Прослушайте и подумайте, к какой части сказки Пушкина оно подходит? Почему? (звучить п'єса «Політ джмеля» $з$ опери Н. А. РимськогоКорсакова «Казка про царя Салтана».)

Учитель после прослушивания: С какой частью произведения А. С. Пушкина можно его соотнести? А каким звуком вы бы передали этот момент в произведении?

\section{V. Основна частина уроку}

\section{1. Вправа «Реконструкція»}

Учитель: Восстановите названия сказок А. С. Пушкина, в которых «потерялись» гласные, и запишите их. Смогли бы вы угадать названия, если бы были записаны только гласные?

«Ск_зк__ц_р_С_лт_н_», «СК_зК_- 3 л_т м п т шк_», «СК_зК_- М_ртв_й ц_р_вн_- с_М_б_Г_Т р_х», «СК_зк_- р_б_к_- р_бк_", «Ск_зК_ п_п_- р_б_ тн_К__Г_Б_лд_", «СК_зК_- М_дв_д_х_", 《Ж_н_х

\section{2. Робота з сюжетом казки}

\section{Робота в групах (по 6-8 учнів)}

Учитель: Не стоит забывать об одной особенности всего творчества А. С. Пушкина и этой сказки в том числе - об умелом владении словом. Многие строки, созданные поэтом, стали крылатыми и вошли в состав русского языка, их знает и употребляет большое количество людей. С крылатыми словами сейчас и поработаем. Мы уже сегодня говорили о том, что такое крылатое выражение, давайте-ка вспомним ещё раз, что это такое? (Дети отвечают.) Сейчас каждая группа получит список крылатых выражений из этой сказки. Ваше задание расставить эти крылатые выражения в том порядке, в котором они встречались в тексте, и подобрать к ним картинки (иллюстрации к сказке) на экране.
Список крылатых выражений для работы:

1) Три девицы под окном.

2) Кабы я была царица.

3) Родила царица в ночь / Не то сына, не то дочь; / Не мышонка, не лягушку, / А неведому зверушку.

4) И растёт ребёнок там / Не по дням, а по часам.

5) Могучий избавитель. (Царевна-лебедь)

6) Блещут маковки церквей.

7) В колымагах золотых / Пышный двор встречает их.

8) Князь Гвидон.

9) Ветер на море гуляет / И кораблик подгоняет.

10) Чем вы, гости, торг ведёте / И куда теперь плывёте? (Гвидон)

11) Мы объехали весь свет. (Купцы)

12) Мимо острова Буяна, / В царство славного Салтана...

13) Добрый путь вам, господа, / По морю по Окияну / К славному царю Салтану; / От меня ему поклон. (Гвидон)

14) Глядь - поверх текучих вод / Лебедь белая плывёт.

15) Здравствуй, князь ты мой прекрасный? / Что ты тих, как день ненастный? / Опечалился чему? (Царевна-лебедь)

16) Грусть-тоска меня съедает. (Гвидон)

17) А ткачиха с поварихой, / С сватьей бабой Бабарихой.

18) Ой вы, гости-господа, / Долго ль ездили? куда? / Ладно ль за морем иль худо? / и какое в свете чудо?

19) За морем житьё не худо.

20) Белка песенки поёт / И орешки все грызёт.

21) Ядра - чистый изумруд.

22) А комар-то злится, злится.

23) Во саду ли, в огороде...

24) Ель растёт под тем дворцом, / А под ней хрустальный дом.

25) И очутятся на бреге, / В чешуе, как жар горя, / Тридцать три богатыря, / Все красавцы молодые, / Великаны удалые, / Все равны, как на подбор, / С ними дядька Черномор.

26) Полет Шмеля.

27) За морем царевна есть, / Что не можно глаз отвесть: / Днём свет божий затмевает, / Ночью землю освещает, / Месяц под косой блестит, / А во лбу звезда горит.

28) Но жена не рукавица: / С белой ручки не стряхнёшь / Да за пояс не заткнёшь.

29) Тридевять земель.

30) Ведь царевна - это я.

31) Вышел вон и дверью хлопнул.

32) Я там был; мед, пиво пил - / И усы лишь обмочил. 

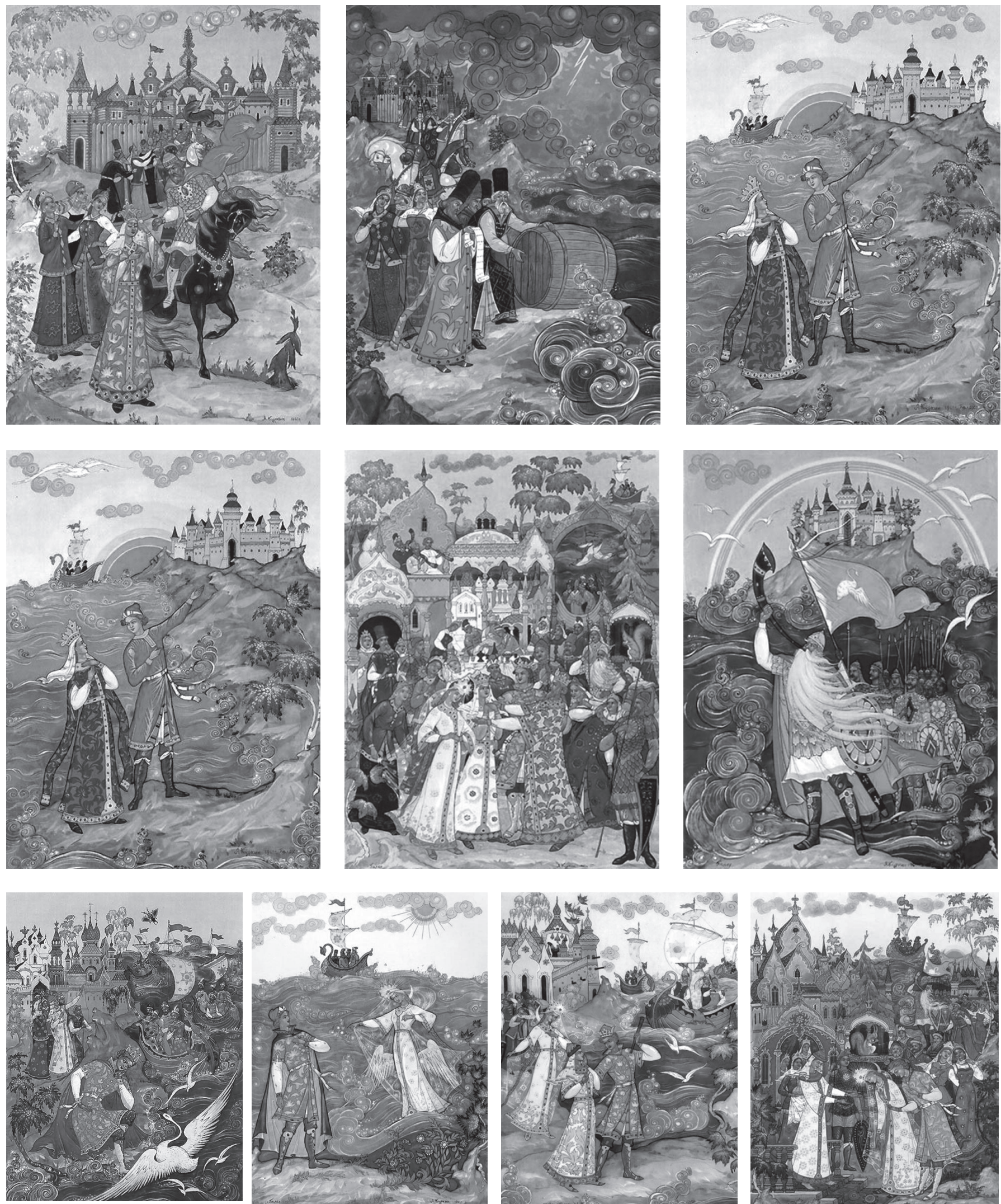

Рис. 1. Иллюстрации к произведению А. С. Пуикина «Сказка о ичыре Салтане» 


\section{3. Мовні вправи}

Учитель: Ребята, давайте вспомним с вами что мы знаем о буквах и звуках русского языка. О них мы говорили в начале урока для этого выполните в тетрадях следующие задания:

1. Из приведённых крылатых выражений выпишите по 10 слов, в которых одинаковое количество букв и звуков, и 10, в которых количество букв и звуков разное.

2. Выпишите из приведённых крылатых выражений слова, в которых одинаковое количество гласных и согласных звуков.

\section{4. Гра «Шифрувальник»}

Учитель: Помните, в начале урока мы с вами играли в игру, где расшифровывали название сказок А. С. Пушкина? Теперь же я предлагаю вам стать шифровальщиками: зашифруйте два понравившиеся крылатые выражения (на выбор). Но помните, что мы убираем только гласные. Итак, шифруете, а потом обмениваетесь с соседом по парте зашифрованными записями. Расшифруйте их и объясните ход своих мыслей. У вас получилось? Кто быстрее всех справился с этим заданием?

\section{5. Робота з ілюстраціями}

Учитель: вы же помните, что с нами сегодня Джон? Он спрашивает, что это за картинки появились на экране. Давайте расскажем ему, что изображено на них. (На экране появились иллюстрации к сказке.)

1. What and who can we see in the first picture? Where are the heroes? What are they doing? What clothes do they wear? Who is this boy for this woman? Who is this woman for this boy?

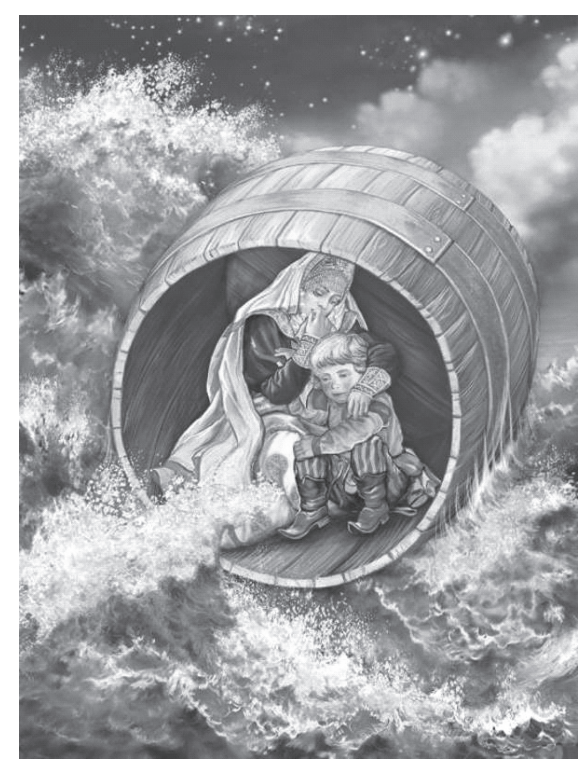

2. What can we see in the second picture? Who is this man? What is he doing? What clothes does he wear? What season is in the picture?

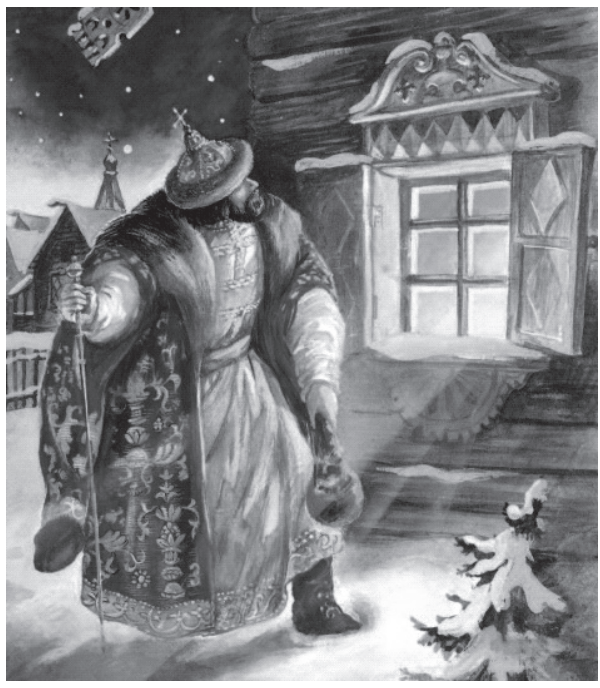

3. What can we see in the third picture? How many heroes can we see? Who are they? What are they doing? What clothes does the prince wear?

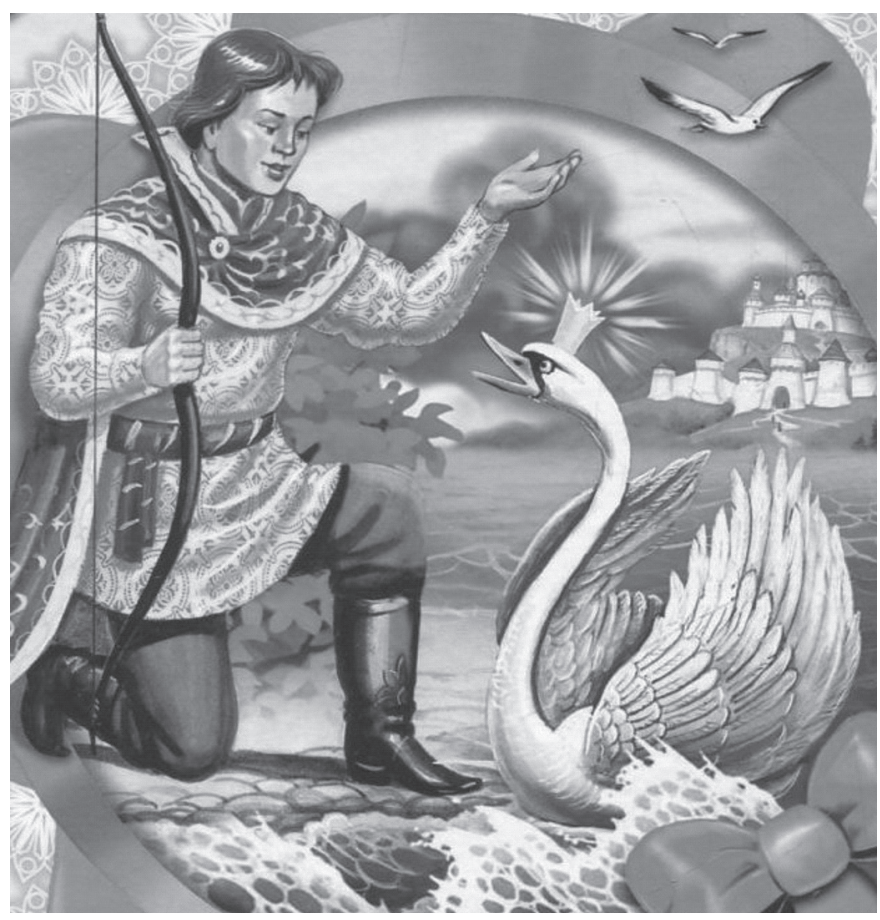

Puc.4

\section{Фізкультхвилинка}

Учитель: дети, мы уже сегодня слушали «Полёт шмеля», а теперь я предлагаю вам встать из-за парт, представить себя шмелём и под музыку показать, как вы летите. Двигаемся по классу по часовой стрелке, а как только музыка прекратится, мы спокойно занимаем свои места. 


\section{VI. Систематизація матеріалу}

\section{1. Вправа «Реконструкція»}

Учитель: Наш урок подходит к концу, предлагаю вам восстановить крылатые выражения, с которыми мы сегодня работали:

Три под окном.

Кабы я была

Родила царица в ночь / Не то , не то

Не мышонка, не лягушку, / А неведому зверушку.

И растёт там / Не по дням, а по часам. избавитель.

Блещут маковки

Князь

Мимо острова Буяна, / В царство славного

(девицы, царица, сына, дочь, ребёнок, могучий, церквей, Гвидон, Салтана).

\section{2. Вправа «Редактор»}

Учитель: Я предлагаю вам перевоплотиться в редакторов, найти неточности в утверждениях и исправить их:

1. В квадратных скобках записывают буквы (звуки).

2. Буквы - это слышимые оболочки букв (звуки это...).

3. Для письменной речи используют звуки (устной речи).

4. Гласные звуки бывают твёрдые и мягкие (согласные).

5. Согласные звуки бывают ударными и безударными (гласные).

\section{3. Вправа «Знайди зайве»}

Учитель: Ребята, прочитайте выражения («Я там был: мед, пиво, пил», «Белка песенки поет»), посчитайте количество звуков в словах, найдите лишние слова (в котором больше или меньше звуков, чем у всех остальных) и объясните почему вы выбрали эти слова.

Два лишних, догадайтесь, что именно лишнее и почему: Я там был: мёд, пиво, пил («я» и «пиво», у остальных по три звука в слове).

Одно лишнее, почему: Белка песенки поёт («песенки» лишнее (семь звуков), «белка» и «поёт» - по пять звуков).

\section{4. Вправа «Упізнай»}

Учитель: Сейчас вы услышите два аудиоотрывка, скажите, какой из них вам знаком, он же связан со сказкой А. С. Пушкина. Что вы о нём уже знаете? Понравился ли он вам? Почему?

Звучит произведение «Полёт шмеля» Н. А. Римского-Корсакова и ещё одно произведение (любое, можно «Танец маленьких лебедей» из балета П. И. Чайковского «Лебединое озеро»; дети должны узнать «Полёт шмеля»).

\section{VII. Підведення підсумків уроку}

Учитель: сегодня мы с вами провели необычный урок, на котором повторили звуки и буквы, вспомнили сказку А. С. Пушкина, вспомнили из неё крылатые выражения, объясняли их значение и попробовали их употребить в речи, рассказали о сказке нашему иностранному гостю, послушали музыку. А теперь вернёмся к эпиграфу, который начинал наш урок, прочитаем его ещё раз. Как вы думаете, почему к этому уроку я выбрала именно это крылатое выражение?

\section{Метод «Прес»}

Учитель: давайте подведём итоги и определим, что вы сегодня узнали, что было для вас новым. На доске схема вашего высказывания:

Сегодня на уроке я узнал, что...

Новым для меня было...

Не забудьте, что Джону тоже интересно, что вы думаете об этом уроке, поэтому рядом с высказыванием по-русски мы пишем и по-английски, вот начало для вас:

It was... (amazing, interesting, cool, informative, unbelievable...).

\section{VII. Пояснення домашнього завдання.}

Учитель: вашим заданием будет изобразить два крылатых выражения из сказки А. С. Пушкина с помощью рисунка.

Отримано 16.07.2020 p. 